\title{
First report of beet pseudo-yellows virus in lettuce in Greece
}

\author{
Vasileia Gavrili $^{1} \cdot$ Chrysoula G. Orfanidou ${ }^{1} \cdot$ Nikolaos I. Katis $^{1} \cdot$ Varvara I. Maliogka ${ }^{1}$ (1)
}

Received: 13 March 2021 / Accepted: 22 July 2021 / Published online: 3 August 2021

(c) Società Italiana di Patologia Vegetale (S.I.Pa.V.) 2021

Keywords Crinivirus $\cdot$ BPYV $\cdot$ Detection $\cdot$ Lettuce

Lactuca sativa L. is an important leafy crop in the Mediterranean countries and worldwide. In November 2020, interveinal yellowing symptoms and slight leaf curling, which resembled infection by criniviruses or poleroviruses, appeared in a fieldgrown lettuce crop in Vassilika (Northern Greece) one of the most important vegetable producing areas in Thessaloniki region. The affected plants comprised about $30 \%$ of the whole crop. In order to unravel the etiology of the disease, 10 samples collected from diseased plants and 4 from asymptomatic ones were initially tested for the presence of poleroviruses using a generic, two-step RT-PCR protocol described by Lotos and colleagues (2014). Nevertheless, the results showed that both symptomatic and asymptomatic plants were negative to polerovirus infection. Therefore, samples were subsequently subjected to one-step RT-PCR assay using the primer set BPYVI/BPYVII (Boubourakas et al. 2006), which amplifies a fragment of $251 \mathrm{nt}$ from the heat-shock protein 70 homologue of beet pseudo-yellows virus (BPYV). Also, one more primer set was used BPYVIII (5'-GAGTGCCTACAATTTCATTCA TCG-3')/BPYVIV(5'-TTCGGTTTCATGTCTCCCTTG-3'), amplifying a fragment of $460 \mathrm{nt}$ from the RNA- dependent RNA polymerase (RdRp) of BPYV. The virus was detected in all (10) symptomatic but not in the asymptomatic (4) ones and two of them tentatively named 'LeVa1' and 'LeVa3' were selected for Sanger sequencing. BLASTn analysis of both genomic regions showed very high sequence similarity (>99\%) between Greek isolates 'LeVal'(MW620202MZ476041) and 'LeVa3'(MW620203-MZ476042) and the isolate 'MI' from Japan (LC100132). BPYV is endemic in cucurbit crops in Greece for more than 20 years especially in Northern Greece where Trialeurodes vaporariorum West., the

Varvara I. Maliogka

vmaliogk@agro.auth.gr

1 Laboratory of Plant Pathology, School of Agriculture, Aristotle University of Thessaloniki, 54124 Thessaloniki, Greece vector of BPYV, is highly abundant (Orfanidou et al. 2019). However, this is the first time we detected the virus in lettuce crops. Future research is required to investigate the spread of the virus in lettuce and potentially in other crops in the region that are often infested by $T$. vaporariorum.

Funding No funding was received for conducting this study.

\section{Declarations}

Conflict of interest The authors declare that they have no conflict of interest.

\section{References}

Boubourakas IN, Avgelis AD, Kyriakopoulou PE, Katis NI (2006) Occurrence of yellowing viruses (Beet pseudo-yellows virus, Cucurbit yellow stunting disorder virus and Cucurbit aphidborne yellows virus) affecting cucurbits in Greece. Plant Pathol 55:276-283. https://doi.org/10.1111/j.1365-3059.2006.01341.x

Lotos L, Efthimiou K, Maliogka VI, Katis NI (2014) Generic detection of poleroviruses using an RT-PCR assay targeting the RdRp coding sequence. J Virol Methods 198:1-11. https://doi.org/10. 1016/j.jviromet.2013.12.007

Orfanidou CG, Papayiannis LC, Pappi PG, Katis NI, Maliogka VI (2019) Criniviruses associated with cucurbit yellows disease in Greece and Cyprus: an ever-changing scene. Plant Pathol 68:764-774

Publisher's Note Springer Nature remains neutral with regard to jurisdictional claims in published maps and institutional affiliations. 